\title{
Choriogonadotropin Beta Measurement
}

National Cancer Institute

\section{Source}

National Cancer Institute. Choriogonadotropin Beta Measurement. NCI Thesaurus. Code C64851.

A determination of the presence of Choriogonadotropin Beta protein. 